$$
D P-429
$$

METALLURGY AND CERAMICS

(TID-4500, 15th Ed.)

\title{
CORROSION OF STAINLESS STEEL IN THOREX PROCESS SOL.UTIONS
}

\author{
by \\ Patricia M. Kranzlein \\ Work done by \\ M. L. Hol zworth \\ Savannah River Laboratory \\ and \\ J. A. Snyder \\ Engineering Research Laboratory \\ December 1959
}

\author{
E. I. du Pont de Nemours \& Co. \\ Explosives Department - Atomic Energy Division \\ Technical Division - Savannah River Laboratory \\ Printed for \\ The United States Atomic Energy Commission \\ Contract AT( 07-2)-1
}




\section{DISCLAIMER}

This report was prepared as an account of work sponsored by an agency of the United States Government. Neither the United States Government nor any agency Thereof, nor any of their employees, makes any warranty, express or implied, or assumes any legal liability or responsibility for the accuracy, completeness, or usefulness of any information, apparatus, product, or process disclosed, or represents that its use would not infringe privately owned rights. Reference herein to any specific commercial product, process, or service by trade name, trademark, manufacturer, or otherwise does not necessarily constitute or imply its endorsement, recommendation, or favoring by the United States Government or any agency thereof. The views and opinions of authors expressed herein do not necessarily state or reflect those of the United States Government or any agency thereof. 


\section{DISCLAIMER}

Portions of this document may be illegible in electronic image products. Images are produced from the best available original document. 


\begin{abstract}
The corrosion of $304 \mathrm{~L}$ and $309 \mathrm{SCb}$ stainless steel was studied in $\mathrm{HF}-\mathrm{HNO}_{3}$ solutions proposed for the Thorex process. Except for the dissolving and waste evaporation steps in the Thorex process, corrosion of $304 \mathrm{~L}$ and $309 \mathrm{SCb}$ is not expected to exceed that experienced in the Purex process. To minimize the high initial corrosion rate of $309 \mathrm{SCb}$ in the boiling $\mathrm{HF}-\mathrm{HNO}_{3}$ dissolving solution, a heel of thorium should be maintained in the dissolver. The corrosion rate of $304 \mathrm{~L}$ in the low activity waste evaporator can be reduced by adding one mole of aluminum per mole of fluoride to the evaporator feed.
\end{abstract}




\section{CONTENTS}

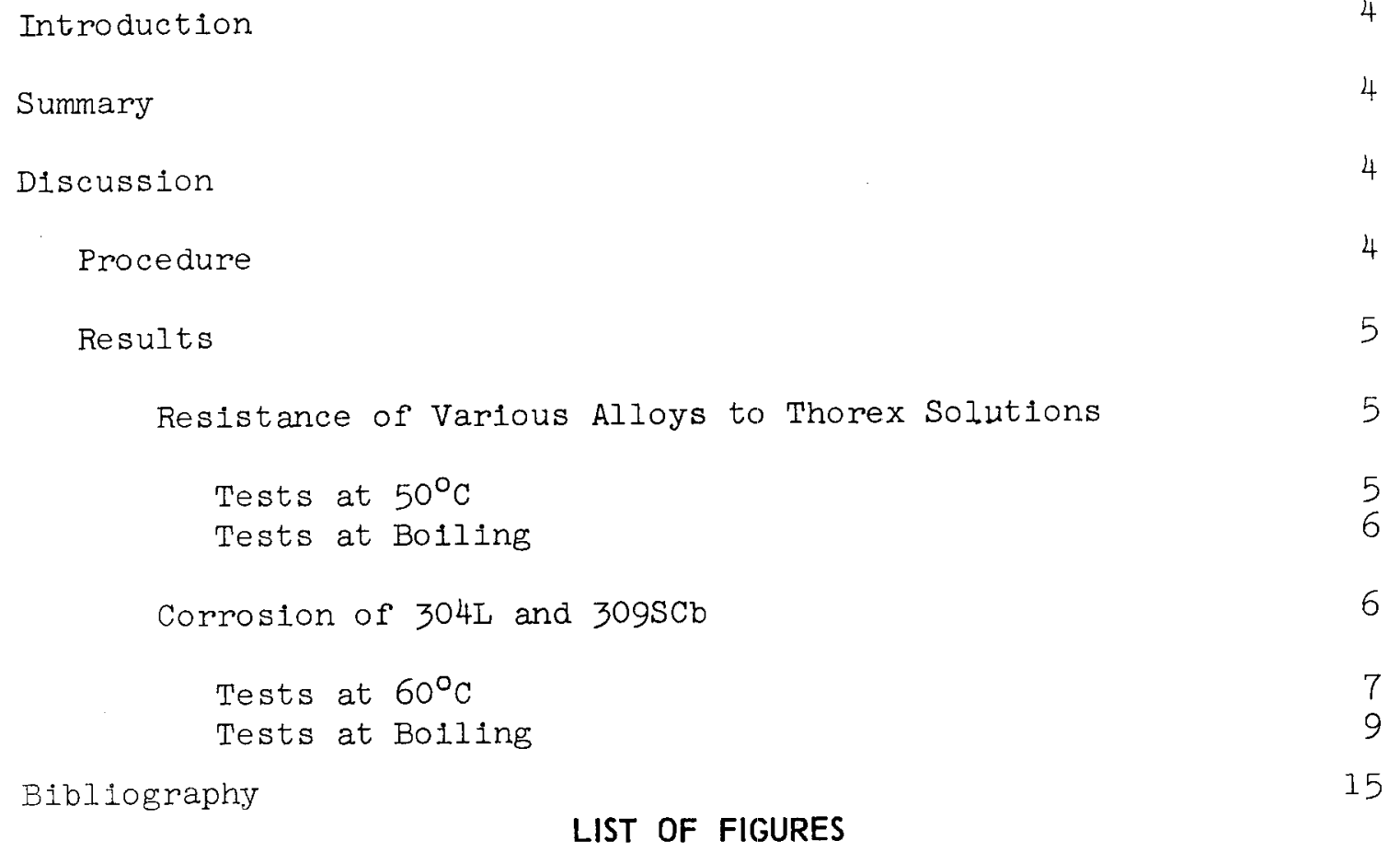

Page

4

\section{Figure}

1 Corrosion of $304 \mathrm{~L}$ in Bolling $0.05 \mathrm{M} \mathrm{HF}$ Solutions Containing $\mathrm{HNO}_{3}$ and $\mathrm{Th}\left(\mathrm{NO}_{3}\right)_{4}$

2 Corrosion of $304 \mathrm{~L}$ in Boiling 0.1M HF Solutions Containing $\mathrm{HNO}_{3}$ and $\mathrm{Th}\left(\mathrm{NO}_{3}\right)_{4}$

3 Corrosion of $309 \mathrm{SCb}$ in Boiling $0.05 \mathrm{M} \mathrm{HF}$ Solutions Containing $\mathrm{HNO}_{3}$ and $\mathrm{Th}\left(\mathrm{NO}_{3}\right)_{4}$

4 Corrosion of $309 \mathrm{SCb}$ in Bolling 0.1M HF Solutions Containing $\mathrm{HNO}_{3}$ and $\mathrm{Th}\left(\mathrm{NO}_{3}\right)_{4}$ 


\section{CORROSION OF STAINLESS STEEL IN THOREX PROCESS SOLUTIONS}

\section{INTRODUCTION}

In the Thorex process for the separation of $U^{233}$ from irradiated thorium, the dissolution of thorium in $\mathrm{HNO}_{3}$ requires the addition of $\mathrm{HF}$ to catalyze the reaction and to prevent formation of a protective film on the thorium. The addition of $\mathrm{HF}$ to the process solutions introduces a corrosion problem when these solutions are handled in stainless steel equipment. The objective of the work described in this report was to evaluate the seriousness of the corrosion problem that would arise if the Thorex process were operated in some existing stainless steel equipment in the Separations Area of the Savannah River Plant. The results of laboratory corrosion tests are reported here; corrosion data obtained during experimental dissolutions are given in DP-399.

\section{SUMMARY}

Except for the dissolving and waste evaporation steps in the Thorex process, corrosion of the stainless steel equipment in the Separations Area is not expected to exceed that experienced with the Purex process for separating plutonium from irradiated uranium.

The dissolver solutions, $10 \mathrm{M} \mathrm{HNO}_{3}$ and from 0.05 to $0.1 \mathrm{M} \mathrm{HF}$, corrode wrought $309 \mathrm{SCb}$ at a rate of from 205 to $365 \mathrm{mpy}$ (mils per year). A corrosion rate of approximately $25 \mathrm{mpy}$ is considered to be the maximum allowable rate for satisfactory service life. Welds of $3095 \mathrm{sb}$ corrode up to a rate 20 times higher than the wrought metal. As thorium dissolves, the corrosion rate of $309 \mathrm{SCb}$ decreases until at a concentration of 1 . OM $\mathrm{Th}\left(\mathrm{NO}_{3}\right)_{4}$ the corrosion rate is less than $10 \mathrm{mpy}$. To minimize the severe initial corrosion in the $\mathrm{HF}^{-\mathrm{HNO}_{3}}$ dissolver solution, a heel of thorium should be maintained in the dissolver.

In the evaporation cycle the corrosion rate of $304 \mathrm{~L}$ exceeds $110 \mathrm{mpy}$ in simulated low activity waste solutions after concentration. The addition of aluminum to complex the fluoride in a molar ratio of $1: 1$ reduced the corrosion rate of $304 \mathrm{~L}$ to $22 \mathrm{mpy}$. No preferential weld corrosion occurs when $304 \mathrm{~L}$ is welded with $308 \mathrm{~L}$ filler rod. However, 347 welds corrode preferentially.

\section{DISCUSSION}

\section{PROCEDURE}

Conventional gravimetric corrosion test procedures were used. Generally, tests were conducted for five 48-hour periods. At temperatures below the boiling point, tests were run in "Saran" pipe sections or polyethylene containers in constant temperature water baths. "Teflon"lined spool pieces were used for tests at boiling point. All coupons were supported on "Teflon" sample holders. 
RESULTS

RESISTANCE OF VARIOUS ALLOYS TO THOREX SOLUTIONS

Tests at $50^{\circ} \mathrm{C}$

The relative corrosion resistance of a variety of alloys was evaluated in simulated Thorex solutions to determine whether existing plant equipment was adequate for handling $\mathrm{HF}_{-} \mathrm{HNO}_{3}$ solutions. For screening tests a solution of $10.3 \mathrm{M} \mathrm{HNO}_{3}$ and $0.33 \mathrm{M} \mathrm{HF}$ at $50^{\circ} \mathrm{C}$ was used. Additions of $\mathrm{Th}\left(\mathrm{NO}_{3}\right)_{4}$ were made to simulate the solution after part of the thorium had been dissolved. Also, the effect of aluminum in the $\mathrm{HF}-\mathrm{HNO}_{3}$ solution was studied. Results are reported in the following table.

Corrosion of Alloys

in Simulated Thorex Solutions at $50^{\circ} \mathrm{C}$

Solution Composition, M

Corrosion Rate, mpy

\begin{tabular}{|c|c|c|c|c|c|c|c|c|c|c|c|c|}
\hline $\mathrm{HF}$ & $\mathrm{HNO}_{3}$ & $\operatorname{Th}\left(\mathrm{NO}_{3}\right)_{4}$ & $\mathrm{Al}\left(\mathrm{NO}_{3}\right)_{3}$ & $\mathrm{AlF}_{3}$ & $304 \mathrm{~L}$ & $309 \mathrm{SCb}$ & 310 & 329 & 347 & 430 & 446 & $\begin{array}{c}\text { Carp. } \\
20 \\
\end{array}$ \\
\hline 0.33 & 10.3 & - & - & - & 93 & 31 & 23 & 110 & 264 & 230 & 139 & 71 \\
\hline 0.33 & 10.3 & 0.012 & - & - & 66 & 30 & 22 & 106 & 236 & 145 & 61 & 74 \\
\hline 0.33 & 10.3 & 0.1 .22 & - & - & 3.5 & 2.7 & 2.0 & 1.8 & 3.8 & 4.8 & 4.1 & 3.3 \\
\hline 0.33 & 10.3 & - & 0.176 & - & 9.0 & 6.0 & 5.0 & 7.0 & 19 & 17 & 6.0 & 9.0 \\
\hline - & 10.3 & - & - & 0.33 & 8.0 & 6.0 & 7.0 & 8.0 & 20 & 19 & 7.0 & 9.0 \\
\hline
\end{tabular}

Of the wrought alloys tested, 310 had the lowest corrosion rate in the $\mathrm{HF}-\mathrm{HNO}_{3}$ solutions. However, the corrosion rate of $309 \mathrm{SCb}$ was only slightly higher than 310, so that replacement of the existing $309 \mathrm{SCb}$ equipment would not be justified. Type 304L and Carpenter 20 were next in corrosion resistance.

Thorium complexed the fluoride and reduced the corrosion rate of stainless steel. At $50^{\circ} \mathrm{C}$ the addition of $0.122 \mathrm{M} \mathrm{Th}\left(\mathrm{NO}_{3}\right)_{4}$ lowered the corrosion rate of all the alloys to less than $5 \mathrm{mpy}$ in the $10.3 \mathrm{M} \mathrm{HNO}_{3}$ and $0.33 \mathrm{M} \mathrm{HF}$ solution. From the corrosion data, it appeared that each mole of thorium was able to complex at least 4 moles of fluoride at $50^{\circ} \mathrm{C}$.

Aluminum also complexed the fluoride and reduced the corrosion rate of stainless steel in $\mathrm{HF}^{-\mathrm{HNO}_{3}}$ solutions. Addition of $0.176 \mathrm{M} \mathrm{Al}\left(\mathrm{NO}_{3}\right)_{3}$ lowered the corrosion rate of all the alloys to less than 20 mpy. In $10.3 \mathrm{M} \mathrm{HNO}_{3}$ solutions containing $0.33 \mathrm{M} \mathrm{AlF} 3$ the corrosion rates of the alloys were approximately the same as in the $10.3 \mathrm{M} \mathrm{HNO}_{3}$ solutions containing $0.33 \mathrm{M} \mathrm{HF}$ and $0.176 \mathrm{M} \mathrm{Al}\left(\mathrm{NO}_{3}\right)_{3}$. From this corrosion data it appeared that each mole of aluminum was able to complex about 3 moles of fluoride in $\mathrm{HF}-\mathrm{HNO}_{3}$ solutions at $50^{\circ} \mathrm{C}$. 
Tests at Boiling

Dissolving experiments by Separations showed that a solution containing $10 \mathrm{M} \mathrm{HNO} \mathrm{H}_{3}$ and between 0.05 and $0.1 \mathrm{M} \mathrm{HF}$ gave a reasonable time cycle for the Thorex process. (1) Therefore, corrosion tests of the various alloys were conducted in the following boiling $\mathrm{HF}-\mathrm{HNO}_{3}$ solutions that were designed to simulate process solutions at various stages.

Corrosion of Alloys

in Boiling Simulated Thorex Solutions

Solution Composition, M

$\mathrm{HF}_{\mathrm{HNO}_{3}} \mathrm{Th}\left(\mathrm{NO}_{3}\right)_{4} \mathrm{AI}_{2}\left(\mathrm{NO}_{3}\right)_{3} \mathrm{NaNO}_{3}$

$\begin{array}{lllllllllllll}0.075 & 10.3 & - & - & - & 390 & 290 & 150 & 233 & 452 & 710 & 390 & 22 \\ 0.05 & 10.3 & - & - & - & 205 & 143 & 105 & - & - & 450 & - & - \\ 0.075 & 10.3 & 0.09 & - & - & 61 & 37 & - & 30 & 68 & 138 & 49 & - \\ 0.075 & 0.5 & 2.0 & - & - & 1.5 & 1.0 & - & - & - & - & - & - \\ 0.009 & 5.6 & - & - & 1.47 & 27 & 13 & - & 13 & 22 & 38 & 20 & - \\ 0.07 & - & - & 0.6 & - & \mathrm{N} 11 & \mathrm{NiI} & - & \mathrm{NiI} & \mathrm{N} 11 \mathrm{Nil} & \mathrm{N} 11 & -\end{array}$

Carp. Tan$304 \mathrm{~L} 309 \mathrm{sCb} 30931032934720$ talum Corrosion Rate, mpy 2

Although tantalum, 309, and 310 corroded at lower rates than $309 \mathrm{SCb}$ or 304L, their corrosion resistance was not superior enough to warrant replacing available $309 \mathrm{SCb}$ and $304 \mathrm{~L}$ process equipment.

The addition of $0.09 \mathrm{M} \mathrm{Th}\left(\mathrm{NO}_{3}\right)_{4}$ to boiling $10.3 \mathrm{M} \mathrm{HNO}$ and $0.075 \mathrm{M} \mathrm{HF}$ solutions reduced the corrosion rate of $309 \mathrm{SCb}$ from 290 to 37 mpy and of $304 \mathrm{~L}$ from 390 to $61 \mathrm{mpy}$.

In a boiling $0.075 \mathrm{M} \mathrm{HF}, 0.5 \mathrm{M} \mathrm{HNO}_{3}$, and 2.0M Th( $\left.\mathrm{NO}_{3}\right)_{4}$ solution, which represented the solution after completion of the dissolving cycle, the corrosion rates of both $304 \mathrm{~L}$ and $309 \mathrm{SCb}$ were less than 2 mpy.

An estimated low activity waste solution containing $0.009 \mathrm{M} \mathrm{HF}, 5.6 \mathrm{M} \mathrm{HNO}_{3}$, and $1.47 \mathrm{M} \mathrm{NaNO} \mathrm{N}_{3}$ corroded $304 \mathrm{~L}$ at $27 \mathrm{mpy}$ and $309 \mathrm{SCb}$ at $13 \mathrm{mpy}$.

The waste from the first-cycle solvent extraction contactors was estimated as $0.07 \mathrm{M} \mathrm{HF}$ and $0.6 \mathrm{M} \mathrm{Al}\left(\mathrm{NO}_{3}\right)_{3}$. The corrosion rate of stainless steel in this solution was negligible.

CORROSION OF $304 \mathrm{~L}$ AND 309SCb

To define further the corrosion behavior of 304L and 309SCb, a series of corrosion studies at varying $\mathrm{HF}, \mathrm{HNO}_{3}$, and $\mathrm{Th}\left(\mathrm{NO}_{3}\right)_{4}$ concentrations were conducted at $60^{\circ} \mathrm{C}$ and the boiling point. 
Tests at $60^{\circ} \mathrm{C}$

Effect of HF

The effect of $\mathrm{HF}$ on the corrosion of $304 \mathrm{~L}$ and $309 \mathrm{SCb}$ was studied in $10 \mathrm{M}$ $\mathrm{HNO}_{3}$ at $60^{\circ} \mathrm{C}$. Results were as follows:

\begin{tabular}{|c|c|c|}
\hline \multirow[b]{2}{*}{$\mathrm{HF}, \mathrm{M}$} & \multicolumn{2}{|c|}{ Corrosion Rate, mpy } \\
\hline & $304 \mathrm{~L}$ & $309 \mathrm{SCb}$ \\
\hline 0.025 & 12 & 10 \\
\hline 0.05 & 25 & 27 \\
\hline 0.075 & 47 & 44 \\
\hline 0.1 & 62 & 54 \\
\hline
\end{tabular}

The corrosion rate was a linear function of the HF concentration for both $304 \mathrm{I}$ and $309 \mathrm{SCb}$.

Effect of $\operatorname{Th}\left(\mathrm{NO}_{3}\right)_{4}$

The effect of $\mathrm{Th}\left(\mathrm{NO}_{3}\right)_{4}$ concentration on the corrosion rate of $304 \mathrm{~L}$ and $309 \mathrm{SCb}$ in $\mathrm{HF}-\mathrm{HNO}_{3}$ solutions is reported in the following table.

Corrosion Rates of Stainless Steel in $10 \mathrm{M} \mathrm{HNO}_{3}$ Solutions Containing $\mathrm{HF}$ and $\mathrm{Th}\left(\mathrm{NO}_{3}\right)_{4}$ at $60^{\circ} \mathrm{C}$

Corrosion Rate, moy

\begin{tabular}{|c|c|c|c|c|}
\hline \multirow[b]{3}{*}{$\operatorname{Th}\left(\mathrm{NO}_{3}\right)_{4}, \mathrm{M}$} & \multirow{2}{*}{\multicolumn{2}{|c|}{$304 \mathrm{I}$}} & \multirow{2}{*}{\multicolumn{2}{|c|}{$309 \mathrm{SCb}$}} \\
\hline & & & & \\
\hline & $0.05 \mathrm{M} \mathrm{HF}$ & $0.1 \mathrm{M} \mathrm{HF}$ & $0.05 \mathrm{M} \mathrm{HF}$ & $0.1 \mathrm{M} \mathrm{HF}$ \\
\hline 0 & 25 & 62 & 27 & 54 \\
\hline 0.003 & 12 & 45 & 12 & 42 \\
\hline 0.01 & 11 & 31 & 8.7 & 20 \\
\hline 0.02 & 6.0 & 14 & 4.1 & $9 \cdot 7$ \\
\hline 0.03 & - & 6.1 & 3.4 & 4.0 \\
\hline 0.3 & 1.2 & 1.9 & 1.0 & 1.3 \\
\hline 0.9 & 0.4 & 1.0 & 0.2 & 0.6 \\
\hline
\end{tabular}

The corrosion rates of both $304 \mathrm{~L}$ and $309 \mathrm{SCb}$ decreased with an increase in $\mathrm{Th}\left(\mathrm{NO}_{3}\right)_{4}$ concentration. In the $60^{\circ} \mathrm{C}$ solutions each mole of thorium complexed about 4 moles of fluoride, reducing the corrosion rate to less than 10 mpy. 


\section{Weld Corrosion Resistance}

Welded samples of both. $304 \mathrm{~L}$ and $309 \mathrm{SCb}$ corroded at much higher rates than wrought samples as reported in the following table. Samples of $304 \mathrm{~L}$ were electric-arc welded with 347 filler rod, and $309 \mathrm{SCb}$ was electric-arc welded with 309SCb filler rod.

\begin{tabular}{|c|c|c|c|c|}
\hline \multicolumn{3}{|c|}{ Solution Composition, $M$} & \multicolumn{2}{|c|}{ Corrosion Rate, mpy } \\
\hline $\mathrm{Th}\left(\mathrm{NO}_{3}\right)_{4}$ & $\mathrm{HF}$ & $\mathrm{HNO}_{3}$ & $304 \mathrm{~L}-\mathrm{AW}$ & $309 \mathrm{SCb}-\mathrm{AW}$ \\
\hline 0.003 & 0.05 & 10.0 & 32 & 44 \\
\hline 0.03 & 0.05 & 10.0 & 6.3 & 4.7 \\
\hline 0.3 & 0.05 & 10.0 & 1.4 & 1.0 \\
\hline 0.003 & 0.1 & 10.0 & 80 & 115 \\
\hline 0.03 & 0.1 & 10.0 & 8 & 5.4 \\
\hline 0.3 & 0.1 & 10.0 & 2.2 & 0.6 \\
\hline
\end{tabular}

The higher corrosion rates of the welded samples were due to preferential corrosion of the $309 \mathrm{SCb}$ and 347 welds.

Samples of all weld metals were tested and the results were as follows:

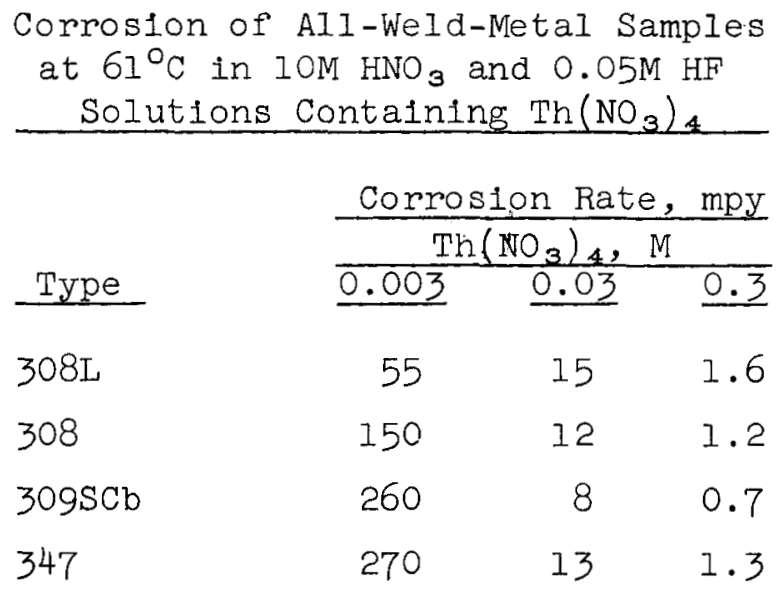

The resistance of 308L weld metal was superior, as has been noted in other work. $(2,3)$ Twice the $\operatorname{Th}\left(\mathrm{NO}_{3}\right)_{4}$ concentration needed for wrought metal was required to reduce the corrosion rate of the weld metal to about 10 mpy. 


\section{Tests at Bolling}

$304 \mathrm{~L}$ in $\mathrm{HF}-\mathrm{HNO}_{3}-\mathrm{Th}\left(\mathrm{NO}_{3}\right)_{4}$

The corrosion rate of $304 \mathrm{~L}$ increased with either an increase in $\mathrm{HF}$ or $\mathrm{HNO}_{3}$ concentration and decreased with an increase in $\mathrm{Th}\left(\mathrm{NO}_{3}\right)_{4}$ concentration. The corrosion data are summarized in the following table. The results are shown graphically in Figure 1 for $0.05 \mathrm{M} \mathrm{HF}$ and in Figure 2 for $0.1 \mathrm{M} \mathrm{HF}$ solutions. In each figure, isocorrosion curves show the combinations of $\mathrm{HNO}_{3}$ and $\mathrm{Th}\left(\mathrm{NO}_{3}\right)_{4}$ required to obtain a specifled corrosion rate with the HF concentration held constant.

Corrosion Rates of $304 \mathrm{~L}$

in Bolling $\mathrm{HF}-\mathrm{HNO}_{3}-\mathrm{Th}\left(\mathrm{NO}_{3}\right)_{4}$ Solutions

\begin{tabular}{|c|c|c|c|c|c|c|c|c|}
\hline \multirow[b]{3}{*}{$\mathrm{Th}\left(\mathrm{NO}_{3}\right)_{4}, \mathrm{M}$} & \multirow[b]{3}{*}{$\underline{\mathrm{HF}, \mathrm{M}}$} & \multicolumn{7}{|c|}{ Corrosion Rate, mpy } \\
\hline & & \multicolumn{7}{|c|}{$\mathrm{HNO}_{3}, \mathrm{M}$} \\
\hline & & 10 & 8 & 6 & 4 & 2 & 1 & 0.5 \\
\hline 0 & 0.05 & 344 & 2.26 & 151 & 114 & 104 & 85 & 63 \\
\hline 0.003 & 0.05 & $206(430) *$ & 178 & - & 96 & 54 & - & 45 \\
\hline 0.03 & 0.05 & $66(139)$ & 38 & - & 9.8 & 2.6 & - & 0.4 \\
\hline 0.1 & 0.05 & 33 & 17 & - & 3.7 & 1.4 & - & 0.3 \\
\hline 0.2 & 0.05 & 20 & 8.4 & - & - & - & - & - \\
\hline 0.3 & 0.05 & $14(22)$ & 6.0 & - & 0.9 & - & - & - \\
\hline 0.6 & 0.05 & - & 4.2 & - & 1.1 & 0.5 & - & - \\
\hline 0.8 & 0.05 & 7.4 & - & - & - & - & - & - \\
\hline 1.0 & 0.05 & - & 4.0 & & 1.5 & 0.8 & - & - \\
\hline 1.5 & 0.05 & - & - & & 1.7 & 0.7 & - & 0.2 \\
\hline 0.03 & 0.075 & 96 & - & - & - & - & - & - \\
\hline 0.3 & 0.075 & 15 & - & - & - & - & - & - \\
\hline 0.8 & 0.075 & 5.8 & - & - & - & - & - & - \\
\hline 0 & 0.1 & 591 & 421 & - & 213 & 201 & - & 103 \\
\hline 0.003 & 0.1 & 575 & 368 & - & 168 & - & - & - \\
\hline 0.02 & 0.1 & - & - & - & - & - & - & 29 \\
\hline 0.03 & 0.1 & 183 & 80 & - & 24 & 5.1 & - & 6.3 \\
\hline 0.1 & 0.1 & 64 & 34 & - & 6.2 & 1.9 & - & 0.4 \\
\hline 0.2 & 0.1 & - & - & - & - & - & - & 0.2 \\
\hline 0.3 & 0.1 & 33 & 15 & - & 3.4 & 1.6 & - & 0.2 \\
\hline 0.6 & 0.1 & 19 & 10 & - & 4.0 & 1.6 & - & - \\
\hline 0.8 & 0.1 & 13 & - & - & - & - & - & - \\
\hline 1.0 & 0.1 & 12 & 7.6 & - & 3.5 & 1.8 & - & 0.1 \\
\hline 1.5 & 0.1 & - & - & - & - & - & - & 0.2 \\
\hline
\end{tabular}

* ( ) Designates samples arc welded with 347 filler rod. 


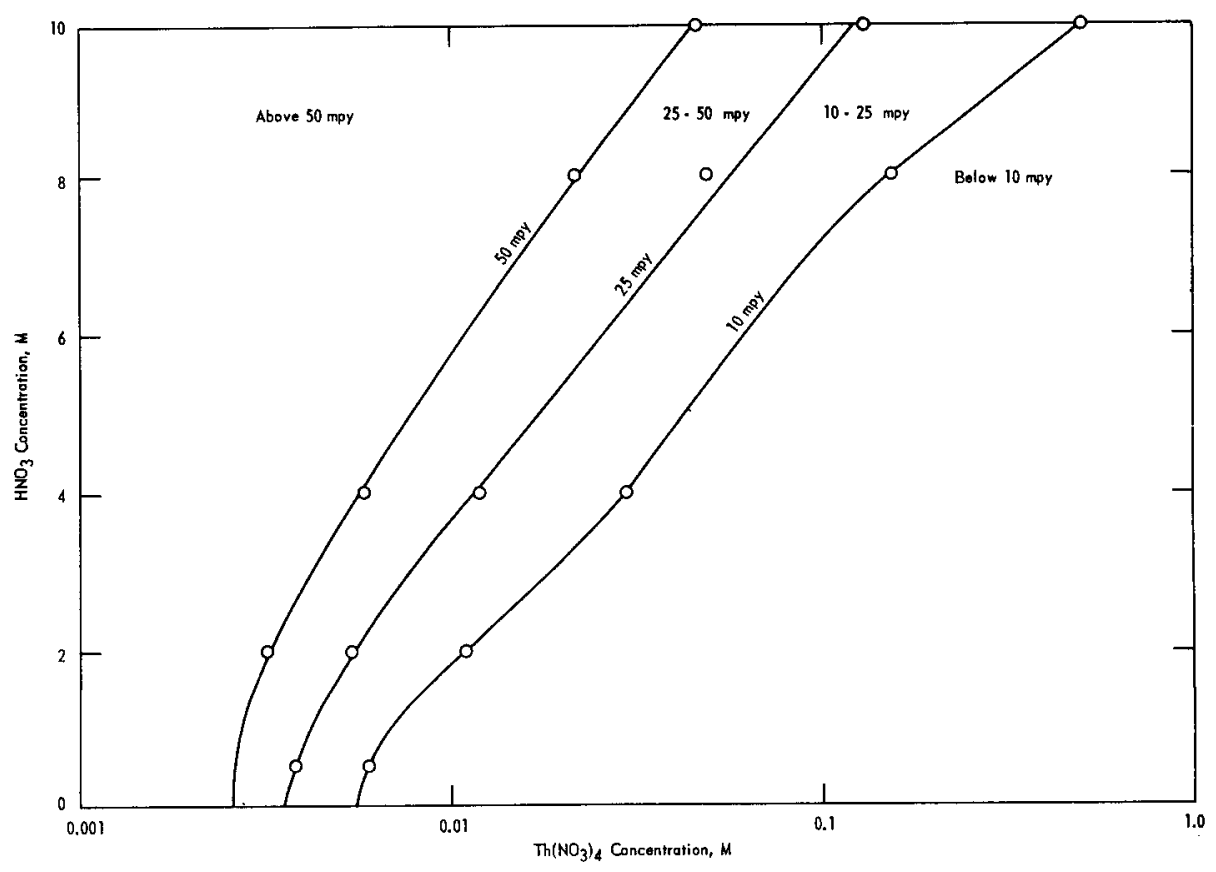

FIGURE 1 - CORROSION OF $304 \mathrm{~L}$ IN BOILING $0.05 \mathrm{M} \mathrm{HF}$ SOLUTIONS CONTAINING $\mathrm{HNO}_{3}$ AND Th( $\left(\mathrm{NO}_{3}\right)_{4}$

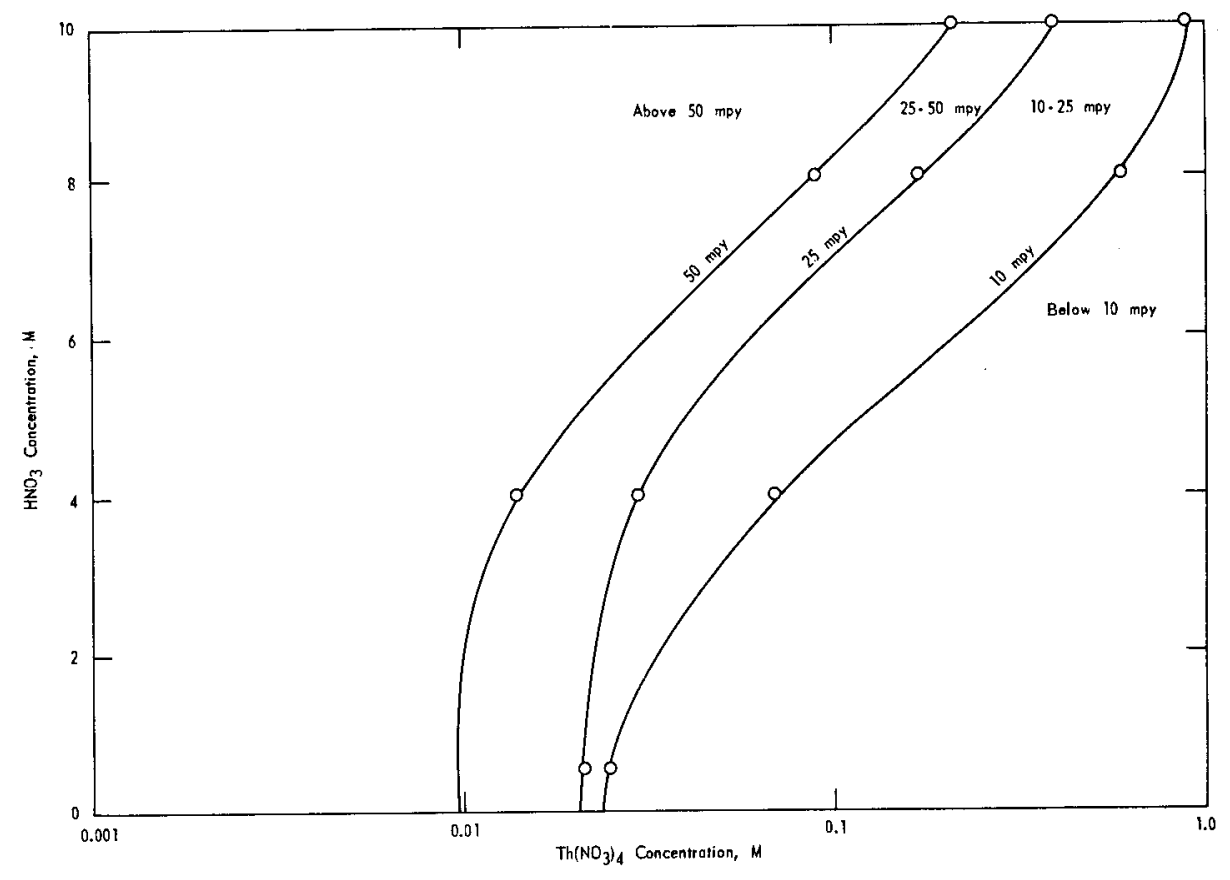

FIGURE 2 - CORROSION OF 304L IN BOILING 0.1M HF SOLUTIONS CONTAINING $\mathrm{HNO}_{3}$ AND Th $\left(\mathrm{NO}_{3}\right)_{4}$ 
During a dissolving cycle without a metal heel, the corrosion would start at a high rate, corresponding to the upper left corner of the Figure 1. As dissolving proceeds, the $\mathrm{HNO}_{3}$ concentration would decrease and the $\mathrm{Th}\left(\mathrm{NO}_{3}\right)_{4}$ concentration would increase, so that the corrosion rate would follow a band across the figure to the lower right corner. With a minimum $\mathrm{Th}\left(\mathrm{NO}_{3}\right)_{4}$ concentration of $0.13 \mathrm{M}$, the corrosion rate of $304 \mathrm{~L}$ was below $25 \mathrm{mpy}$ in $0.05 \mathrm{M} \mathrm{HF}$ and $10 \mathrm{M} \mathrm{HNO}_{3}$. In $0.1 \mathrm{M} \mathrm{HF}$ and $10 \mathrm{M}$ $\mathrm{HNO}_{3}$ solutions about $0.4 \mathrm{M} \mathrm{Th}\left(\mathrm{NO}_{3}\right)_{4}$ was required to reduce the corrosion rate of $304 \mathrm{~L}$ to $25 \mathrm{mpy}$.

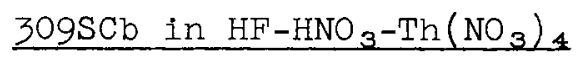

The corrosion resistance of $309 \mathrm{SCb}$ was superior to $304 \mathrm{~L}$ in boiling $\mathrm{HF}-\mathrm{HNO}_{3}-\mathrm{Th}\left(\mathrm{NO}_{3}\right)_{4}$ solutions. The following table summarizes the corrosion data for $309 \mathrm{SCb}$. As for $304 \mathrm{~L}$, the corrosion rate of $309 \mathrm{SCb}$ increased with either an increase in $\mathrm{HF}$ or $\mathrm{HNO}_{3}$ concentration and decreased with an increase in $\mathrm{Th}\left(\mathrm{NO}_{3}\right)_{4}$ concentration.

\section{Corrosion Rates of $3095 \mathrm{Cb}$ \\ in Bolling $\mathrm{HF}-\mathrm{HNO}_{3}-\mathrm{Th}\left(\mathrm{NO}_{3}\right)_{4}$ Solutions}

\begin{tabular}{|c|c|c|c|c|c|c|c|c|}
\hline \multirow[b]{3}{*}{ HF, M } & \multirow[b]{3}{*}{$\operatorname{Th}\left(\mathrm{NO}_{3}\right)_{4}, \mathrm{M}$} & \multicolumn{7}{|c|}{ Corrosion Rate, mpy } \\
\hline & & \multicolumn{7}{|c|}{$\mathrm{HNO}_{3}, \mathrm{M}$} \\
\hline & & 10 & 8 & 6 & 4 & 2 & 1 & 0.5 \\
\hline 0.05 & 0 & 206 & 1.17 & 52 & 23 & 12 & 8.0 & 6.0 \\
\hline 0.05 & 0.003 & $140(365) *$ & 86 & - & 20 & 7.2 & - & 4.3 \\
\hline 0.05 & 0.03 & $36(170)$ & 22 & - & 5.0 & 1.9 & - & 0.1 \\
\hline 0.05 & 0.1 & 18 & 11 & - & 2.9 & 0.5 & - & 0.2 \\
\hline 0.05 & 0.2 & 15 & 7.1 & - & - & - & - & - \\
\hline 0.05 & 0.3 & $12(25)$ & 6.6 & - & 0.6 & - & - & - \\
\hline 0.05 & 0.6 & - & 0.5 & - & 0.4 & 0.3 & - & - \\
\hline 0.05 & 0.8 & 4.1 & - & - & - & - & - & - \\
\hline 0.05 & 1.0 & - & 4.2 & - & 0.5 & 1.2 & - & - \\
\hline 0.05 & 1.5 & - & - & - & 0.8 & 0.4 & - & 0.1 \\
\hline 0.075 & 0.03 & 57 & 29 & - & - & - & - & - \\
\hline 0.075 & 0.3 & 12 & - & - & - & - & - & - \\
\hline 0.075 & 0.6 & - & 4.2 & - & - & - & - & - \\
\hline 0.075 & 0.8 & 2.7 & - & - & - & - & - & - \\
\hline 0.1 & 0 & 364 & 186 & - & 51 & 23 & - & 12 \\
\hline 0.1 & 0.003 & 363 & 164 & - & 39 & - & - & - \\
\hline 0.1 & 0.02 & - & - & - & - & - & - & 5.0 \\
\hline 0.1 & 0.03 & 80 & 39 & - & 7.2 & 2.8 & - & 1.0 \\
\hline 0.1 & 0.1 & 35 & 19 & - & 4.7 & 1.3 & - & 0.2 \\
\hline 0.1 & 0.2 & - & - & - & - & 0.4 & - & 0.1 \\
\hline 0.1 & 0.3 & 23 & 10 & - & 3.1 & 0.5 & - & 0.1 \\
\hline 0.1 & 0.6 & 15 & 8.0 & - & 2.6 & 0.2 & - & - \\
\hline 0.1 & 0.8 & 9.2 & - & - & - & - & - & - \\
\hline 0.1 & 1.0 & 10 & 5.6 & - & 1.8 & 0.5 & - & - \\
\hline 0.1 & 1.5 & - & - & - & - & - & - & 0.1 \\
\hline
\end{tabular}

* ( ) Designates samples arc welded with 3095Cb filler rod. 
Figures 3 and 4 show isocorrosion curves for the corrosion rate of $309 \mathrm{SCb}$ as a function of $\mathrm{HNO}_{3}$ and $\mathrm{Th}\left(\mathrm{NO}_{3}\right)_{4}$ concentration for 0.05 and $0.1 \mathrm{M} \mathrm{HF}$ solutions, respectively. To minimize corrosion of $309 \mathrm{SCb}$ to $25 \mathrm{mpy}$ in $0.05 \mathrm{M} \mathrm{HF}$ and $10 \mathrm{M} \mathrm{HNO}_{3}$ solutions, $0.064 \mathrm{M} \mathrm{Th}\left(\mathrm{NO}_{3}\right)_{4}$ was required. In $0.1 \mathrm{M} \mathrm{HF}$ and $10 \mathrm{M} \mathrm{HNO} \mathrm{HN}_{3}$ solutions a $0.19 \mathrm{M} \mathrm{Th}\left(\mathrm{NO}_{3}\right)_{4}$ concentration was required to reduce the corrosion rate of $309 \mathrm{SCb}$ to $25 \mathrm{mpy}$.

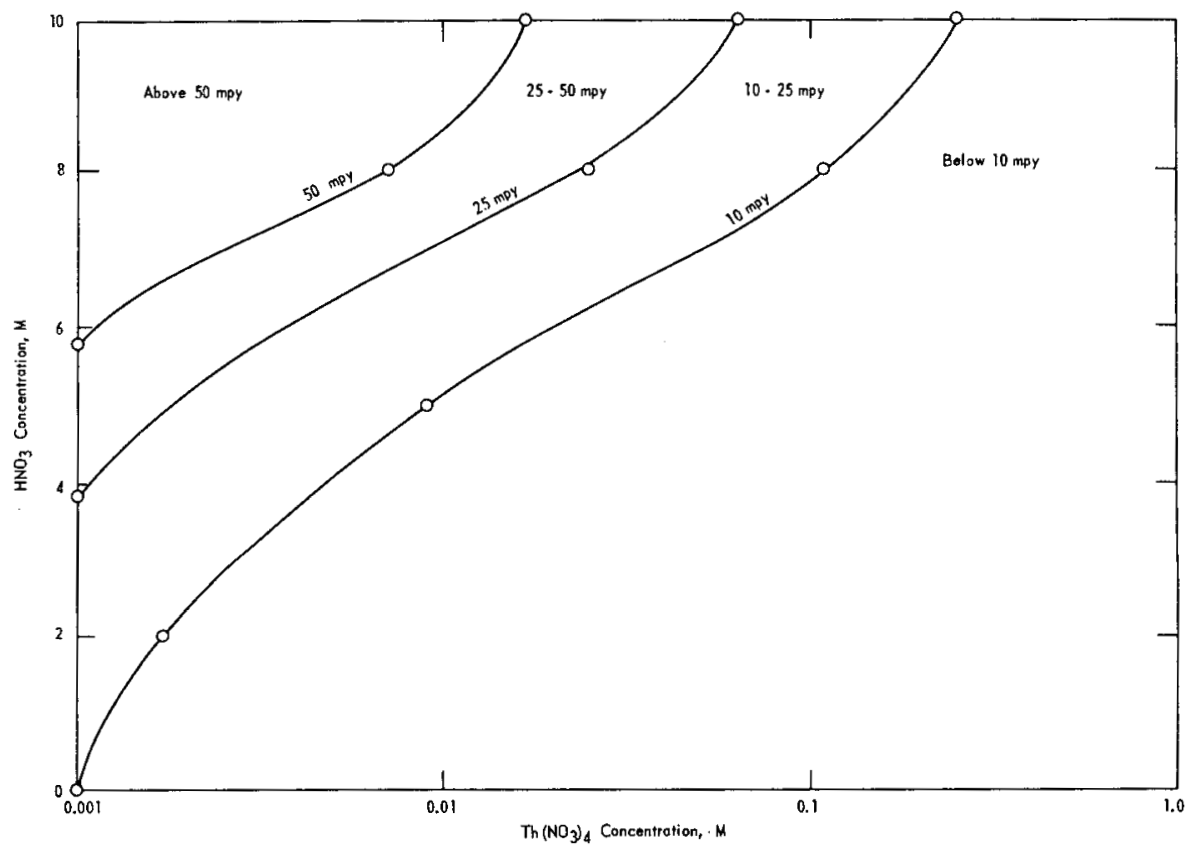

FIGURE 3 - CORROSION OF 309 SCb IN BOILING 0.05M HF SOLUTIONS CONTAINING $\mathrm{HNO}_{3}$ AND Th(NO 3$)_{4}$

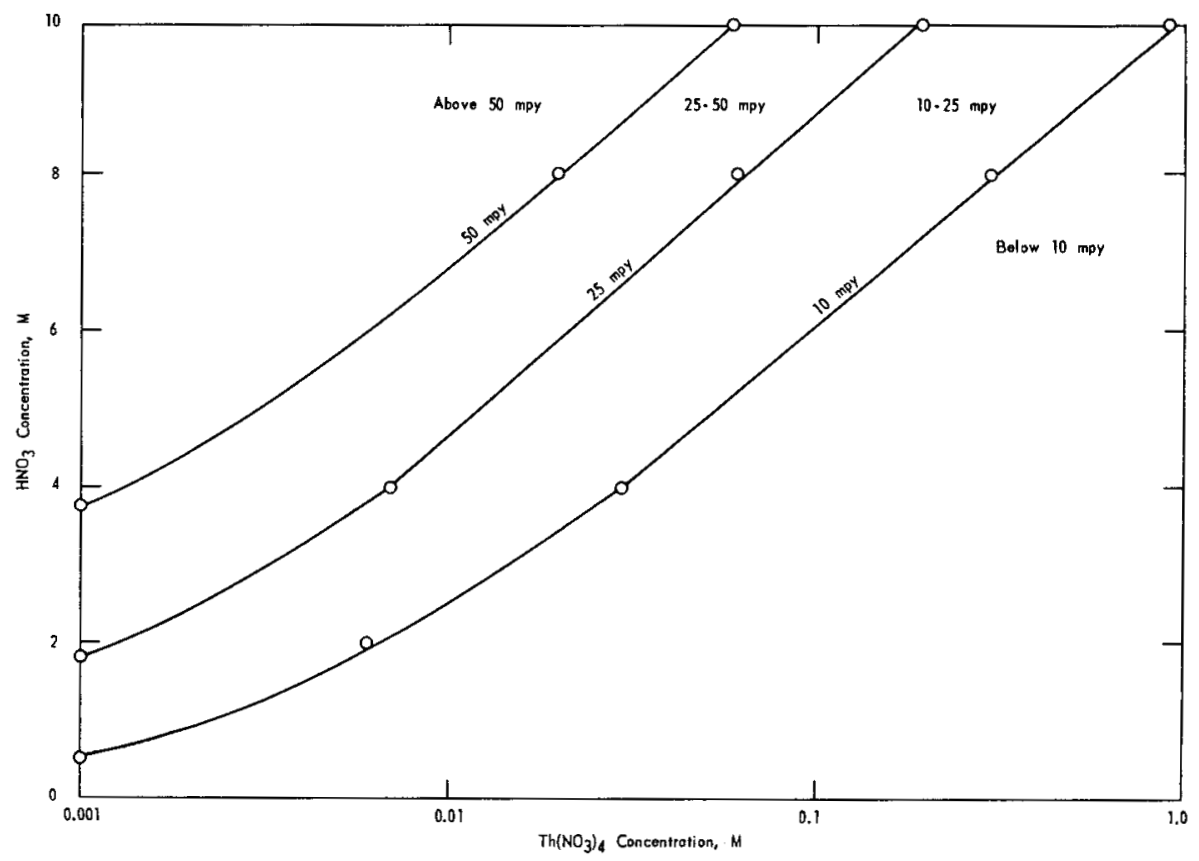

FIGURE 4 - CORROSION OF 309 SCb IN BOILING 0.1M HF SOLUTIONS CONTAINING $\mathrm{HNO}_{3}$ AND $\mathrm{Th}\left(\mathrm{NO}_{3}\right)_{4}$ 
Although thorium reduced the corrosion rate of $309 \mathrm{SCb}$ in boiling $\mathrm{HF}-\mathrm{HNO}_{3}$ solutions, a much higher thorium-to-fluoride ratio was required to decrease the corrosion rate to an acceptable value at the boiling point than was required at $60^{\circ} \mathrm{C}$. In $60^{\circ} \mathrm{C}$ solutions, each mole of thorium was able to complex 4 moles of fluoride. However, in boiling $1 \mathrm{OM} \mathrm{HNO}_{3}$ at least 2 moles of thorium per mole of fluoride were required to reduce the corrosion rate of $309 \mathrm{SCb}$ below $25 \mathrm{mpy}$.

\section{Waste Solutions}

The corrosion of $304 \mathrm{~L}$ and $309 \mathrm{SCb}$ during simulated concentration of the low activity waste solutions is reported in the following table.

$$
\begin{aligned}
& \text { Corrosion of Stainless Steel } \\
& \text { in Boiling Low Activity Waste Solutions }
\end{aligned}
$$

\begin{tabular}{|c|c|c|c|c|c|}
\hline \multicolumn{4}{|c|}{ Solution Composition, M } & \multicolumn{2}{|c|}{$\begin{array}{l}\text { Corrosion } \\
\text { Rate, mpy }\end{array}$} \\
\hline $\mathrm{HNO}_{3}$ & $\mathrm{HF}$ & $\mathrm{Na}_{2} \mathrm{SO}_{4}$ & $\mathrm{NaNO}_{3}$ & $304 \mathrm{~L}$ & $309 \mathrm{SCb}$ \\
\hline 1.26 & 0.006 & 0.004 & 0.015 & 4 & 0.3 \\
\hline 3.2 & 0.02 & 0.016 & 0.51 & 19 & 10 \\
\hline 5.0 & 0.04 & 0.024 & 1.0 & 68 & 26 \\
\hline 6.8 & 0.06 & 0.04 & 1.5 & 112 & 56 \\
\hline
\end{tabular}

As the waste is concentrated, the corrosion rate of the evaporator increases. Although rates were determined for both $304 \mathrm{~L}$ and $309 \mathrm{SCb}$, the present waste evaporators are constructed of $304 \mathrm{I}$.

Effect of Aluminum - To reduce the corrosion rate during evaporation, the effect of adding $\mathrm{Al}\left(\mathrm{NO}_{3}\right)_{3}$ to the concentrated waste solution was studied.

Effect of Aluminum on Corrosion of Stainless steel in a Bolling Concentrated Low Activity Waste Solution $6.8 \mathrm{M} \mathrm{HNO}_{3}, 0.06 \mathrm{M} \mathrm{HF}, 0.04 \mathrm{M} \mathrm{Na}_{2} \mathrm{SO}_{4}, 1.5 \mathrm{M} \mathrm{NaNO}_{3}$

\section{$\mathrm{Al}\left(\mathrm{NO}_{3}\right)_{3}, \mathrm{M}$}

0

0.02

0.04

0.06

0.12
Corrosion Rate, mpy

$\underline{304 \mathrm{~L}} \quad \underline{309 \mathrm{SCb}}$

112 56

$69 \quad 30$

$30 \quad 16$

$22 \quad 10$

66 
A ratio of 1 mole of $\mathrm{Al}\left(\mathrm{NO}_{3}\right)_{3}$ per mole of fluoride was required to reduce the corrosion rate of $304 \mathrm{~L}$ to $22 \mathrm{mpy}$ in the concentrated waste solution. About $0.03 \mathrm{M} \mathrm{Al}\left(\mathrm{NO}_{3}\right)_{3}$, or half the amount required for $304 \mathrm{~L}$, gave a $309 \mathrm{SCb}$ corrosion rate of about $23 \mathrm{mpy}$.

$$
\text { Effect of } \mathrm{Cr}^{6} \text { - Corrosion of stainless steel in Thorex }
$$
solutions introduces $\mathrm{Cr}^{6}$ into the process solutions. Since $\mathrm{Cr}^{6}$ is known to accelerate the corrosion of stainless steel, ${ }^{(4)}$ additions of $\mathrm{CrO}_{3}$ were made to simulated Thorex solutions to determine the resulting corrosion effects.

\section{Effect of $\mathrm{Cr}^{6}$ in Boiling Thorex Solutions}

Solution Composition, $M$

$\mathrm{HNO}_{3} \quad \mathrm{Na}_{2} \mathrm{SO}_{4} \quad \mathrm{NaNO}_{3} \quad \mathrm{CrO}$

\subsection{6}

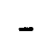

3.06

-

0.2

0.63

6.8

0.2

0.63

0.2

0.63

0.1

$$
0.3
$$

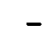

0.1

0.3

6.8 $\underline{\mathrm{Th}\left(\mathrm{NO}_{3}\right)_{4}}$

2.0

2.0

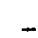

$-$

$-$

$-$

Corrosion

$\frac{\text { Rate, mpy }}{304 \mathrm{I}}$ 309SCb

168 396

350 1100

orrosion

of of both

$304 \mathrm{~L}$ and $309 \mathrm{SCb}$ occurred with $0.1 \mathrm{M} \mathrm{Cr}^{6}$

additions to the process solutions. Generally, the resistance of $309 \mathrm{scb}$ was inferior to that of $304 \mathrm{~L}$ in the solutions containing $\mathrm{Cr}^{6}$.

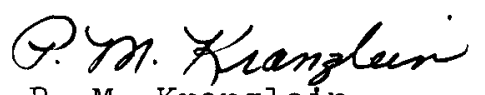

P. M. Kranzlein

Pile Materials Division 


\section{BIBLIOGRAPHY}

1. Karraker, D. G., Dissolution of Thorium in Mixtures of $\mathrm{HNO}_{3}$ and $\mathrm{HF}$. E. I. du Pont de Nemours and Co., DP-399, September 1959.

2. English, J. L., Thorex Pilot Plant Corrosion Studies: I. Corrosion of Types 304L and 309SCb Stainless Steel During Production and Development Periods. Oak Ridge National Lab., ORNL-2673, May 12, 1959.

3. Reprocessing of Power Reactor Fuels - Sixth Quarterly Progress Report - January 1 to April 1, 1959. Compiled by E. S. Occhipinti, E. I. du Pont de Nemours and Co., DP-393, June 1959.

4. Sanborn, K. L., The Effect of Chromium in Nitric Acid Solution on the Corrosion Resistance of Types $304 \mathrm{~L}$ and $309 \mathrm{SCb}$ Stainless steel. Hanford Atomic Products Operation, HW-32877, August 31, 1954. 


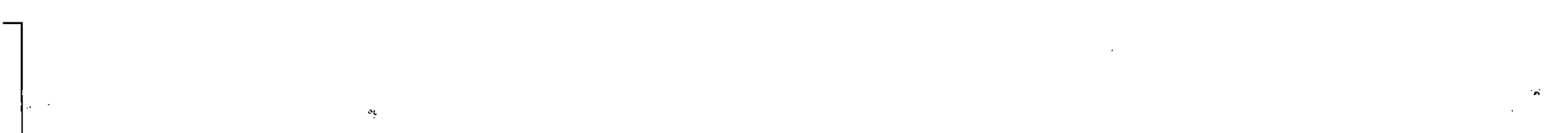

-

-

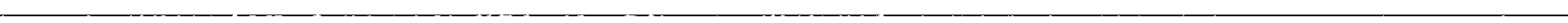

